University of Chicago Law School

Chicago Unbound

Journal Articles

Faculty Scholarship

1993

\title{
Lucas v. South Carolina Coastal Council: A Tangled Web of Expectations
}

Richard A. Epstein

Follow this and additional works at: https://chicagounbound.uchicago.edu/journal_articles

Part of the Law Commons

\section{Recommended Citation}

Richard A. Epstein, "Lucas v. South Carolina Coastal Council: A Tangled Web of Expectations," 45 Stanford Law Review 1369 (1993).

This Article is brought to you for free and open access by the Faculty Scholarship at Chicago Unbound. It has been accepted for inclusion in Journal Articles by an authorized administrator of Chicago Unbound. For more information, please contact unbound@law.uchicago.edu. 


\title{
SYMPOSIUM
}

\section{Lucas v. South Carolina Coastal Council: A Tangled Web of Expectations}

\author{
Richard A. Epstein*
}

\section{INTRODUCTION: DISAPPOINTED EXPECTATIONS}

Although anticipated before its arrival, last term's decision in Lucas $v$. South Carolina Coastal Council ${ }^{1}$ has been rightly regarded as anticlimactic. To be sure, the decision represents something of a high water mark in takings jurisprudence, for a six justice majority of the Court ${ }^{2}$ allowed that some restrictions on land use might in principle be caught by the Takings Clause. But what the Court gave with one hand, it took away with the other. Justice Scalia held that the Takings Clause reached only those land use restrictions that deprived the owner of "all economically beneficial uses" of property. ${ }^{3}$ The proper status of permanent but partial restrictions on land use was not explicitly addressed, but these may now be regarded as legitimate and noncompensable exercises under the state police power. Yet even with total regulatory takings, Justice Scalia stopped short of embracing Lucas's theory that the total loss of beneficial use constitutes a per se compensable taking. Rather, he held that even for total regulatory takings a second test had to be passed as well: If the regulated activity constitutes some form of noxious use or nuisance-like activity subject to regulation at common law, then the state need not compensate the landowner for any resulting economic loss. ${ }^{4}$ Scalia's constitutional edifice thus rests on two critical distinctions. The first is whether the restriction on use is partial or total. If partial, then the constitutional inquiry is at its end, and the restriction is sustained. If total, then

* James Parker Hall Distinguished Service Professor of Law, The University of Chicago.

1. 112 S. Ct. 2886 (1992), rev'g and remanding Lucas v. South Carolina Coastal Council, 304 S.C. 376, 404 S.E.2d 895 (1991).

2. Justices Blackmun and Stevens each wrote an extended and vigorous dissent on the merits, while Justice Souter filed a statement arguing that certiorari should be dismissed as improvidently granted. Lucas, 112 S. Ct. at 2904 (Blackmun, J., dissenting), 2917 (Stevens, J., dissenting), 2925 (Statement of Souter, J., arguing for dismissal of certiorari). Though not considered here, I have addressed the two dissenting opinions in Richard A. Epstein, The Seven Deadly Sins of Takings Law: An Analysis of the Lucas Dissents, 26 LoY. L.A. L. REv. (1993).

3. Lucas, $112 \mathrm{~S}$. Ct. at 2895.

4. The constitutional pedigree of his nuisance test is not always clear. See text accompanying note 39 infra. 
the second criterion must be evaluated: The regulation passes muster only if it restricts some nuisance-like behavior.

The question that $I$ address in this essay is whether the two parts of this edifice can withstand theoretical scrutiny. That inquiry receives a split decision: Suitably refurbished, the nuisance/nonnuisance distinction, which I have defended elsewhere, ${ }^{5}$ does withstand the attacks frequently leveled against it, and its invocation is indispensable for any coherent understanding of the Takings Clause. However, the first half of Scalia's edifice-his distinction between total and partial takings-is so rickety that it must fall of its own weight, as Justice Scalia himself seems to acknowledge, however uneasily. ${ }^{6}$

In order to understand why Justice Scalia's is a house divided, it is necessary to examine the idea of "reasonable expectations" (sometimes unfortunately called "investment-backed expectations") on which his holding so clearly depends. ${ }^{7}$ Neither he nor anyone else offers any telling explanation of why this tantalizing notion of expectations is preferable to the words "private property" (which are, after all, not mere gloss, but actual constitutional text). If "investment-backed expectations" is a term of art designed to convey the idea that property is protected only where it has been acquired by purchase or labor, then it is clearly inaccurate. The government cannot take property from a donee anymore than it can take it from a buyer. If the term is instead designed to stress that protection of private property is granted solely to encourage investment, then its usefulness is still limited by a failure to delineate the nature and scope of the protection, given the apparent ease with which those expectations are so often defeated by a simple appeal to the common good. All in all, we should be deeply suspicious of the phrase "investment-backed expectations" because it is not possible to identify even the paradigmatic case of its use.

Despite its inherent limitations, Justice Scalia relies on the concept of expectations (both the merely reasonable kind and the loftier, investmentbacked variety) at critical points in his analysis. ${ }^{8}$ Justice Kennedy invokes the concept of expectations even more frequently than Justice Scalia, using

5. See Richard A. Epstein, Takings: Private Property and the Power of Eminent Domain 107-45 (1985) [hereinafter EPSTEIN, TAKINGS]; Richard A. Epstein, William H. Mellor III, Clint Bolick, Jonathan W. Emord \& Scott G. Bullock, Brief of the Institute for Justice as Amicus Curiae in Support of Petitioner, Lucas v. South Carolina Coastal Council, 304 S.C. 376, 404 S.E.2d 895 (1991), rev'd and remanded, 112 S. Ct. 2886 (1992) (No. 91-453), reprinted in 25 LoY. L.A. L. REv. 1233, 1248-50 (1992) [hereinafter Amicus Curiae Brief]; Richard A. Epstein, Ruminations on Lucas v. South Carolina Coastal Council: An Introduction to the Amicus Curiae Brief, 25 LOY. L.A. L. REV. 1225 (1992) [hereinafter Epstein, Ruminations].

6. Lucas, 112 S. Ct. at 2894 n.7 ("Regrettably, the rhetorical force of our 'deprivation of all economically feasible use' rule is greater than its precision").

7. See, e.g., the reference in Justice Scalia's majority opinion in Lucas, $112 \mathrm{~S}$. Ct. at $2895 \mathrm{n} .8$, and in Justice Kennedy's concurring opinion at 2903. The phrase was first introduced in Penn Central Transportation Co. v. New York City, 438 U.S. 104, 124 (1978): "The economic impact of the regulation on the claimant and, particularly, the extent to which the regulation has interfered with distinct investment-backed expectations are, of course, relevant considerations." Id. at 124.

8. See, e.g., Lucas, 112 S. Ct. at 2894 n.7. 
the term no less than eleven times in his two-page concurring opinion. ${ }^{9}$ Clearly, the expectations concept is being pressed to do an enormous amount of work in a very complex and troubled area of law. Ironically, however, as its salience increases, its major deficiency_circularity_becomes even more apparent, as Justice Kennedy explicitly acknowledges. ${ }^{10}$

The central difficulty with the Scalia/Kennedy analysis is its failure to explain the relationship between expectations and entitlements, which cannot be unpacked solely by predicting how private parties will behave or how the state will regulate. Instead, defining reasonable expectations turns on a much more complicated inquiry: What set of entitlements maximizes the joint welfare of both the property holder and other affected parties? Democratic institutions are organized for instrumental reasons, the most important of which is to maximize the welfare of the citizens they govern. Therefore, the relevant question at every point should be: Does the regulation or restriction serve to maximize social welfare? If, by our choice of regulation, we can make one person better off while leaving no person worse off, then efficiency counsels us to adopt that particular strategy. Although it is often difficult to implement social reforms with this consequence, ${ }^{11}$ it is a mistake not even to try. And while the choice between the best and the nextbest social arrangement may be difficult to make, either should be preferred over the 100th best allocation of rights, which is the arrangement that current takings law often yields us today.

The Supreme Court's inability to understand the role of reasonable expectations in generating entitlements paves the way for the rapid elimination of all perceived entitlements by simply claiming that the enactment of a single government regulation reasonably creates an expectation that further regulations will follow. With this understanding of expectations, individual property owners are considered "on notice" about the prospect of new legal restrictions on land use and cannot complain when they occur. ${ }^{12}$ Each round of government regulation thus provides justification for the next. In

9. Id. at 2902-04 (Kennedy, J., concurring).

10. Justice Kennedy states:

There is an inherent tendency towards circularity in this synthesis, of course; for if the owner's reasonable expectations are shaped by what courts allow as a proper exercise of governmental authority, property tends to become what courts say it is. Some circularity must be tolerated in these matters, however, as it is in other spheres. E.g. Katz v. United States, 389 U.S. 347, 88 S. Ct. 507, 19 L. Ed. 2 d 576 (1967) (Fourth Amendment protections defined by reasonable expectations of privacy). The definition, moreover, is not circular in its entirety. The expectations protected by the Constitution are based on objective rules and customs that can be understood as reasonable by all parties involved.

Id. at 2903 (Kennedy, J., concurring).

11. Guido Calabresi, The Pointlessness of Pareto: Carrying Coase Further, 100 YALE L.J. 1211, 1212 (1991) (arguing that no moves from the status quo are possible without either disadvantaging someone or shifting the Pareto frontier outward).

12. The notice point is made forcibly in Frank I. Michelman, Property, Utility, and Fairness: Comments on the Ethical Foundations of "Just Compensation" Law, 80 HARV. L. REv. 1165, 1238 (1967). The passage was picked up in HFH, Ltd. v. Superior Court, 15 Cal. 3d 508, 521, 542 P.2d 237, 246, $125 \mathrm{Cal}$. Rptr. 365, 374 (1975). The idea that notice puts a party at risk of future regulation is pervasive in all areas of takings law. See, for example, California Housing Securities, Inc. v. United States, 959 F.2d 955 (Fed. Cir. 1992), for a discussion in connection with banking regulation. 
each successive case, it becomes easier to overwhelm a shattered expectation than it would have been to undo a claim of entitlement to private property. The constant refrain that the Takings Clause protects only investmentbacked or reasonable expectations has thus been used by the Supreme Court to minimize the level of protection given to private property.

This paper is divided into three parts. Part I explores the reasonable expectations idea as employed by Justices Scalia and Kennedy in their respective Lucas opinions. Part II then investigates the many ways the private law uses the term "expectations." Finally, Part III revisits the constitutional questions of expectations and property rights under the Takings Clause.

\section{REASONABLE EXPECTATIONS IN LUCAS}

\section{A. Background Expectations}

The basic facts in Lucas are simple and require only brief recapitulation. In December, 1986, the plaintiff, David Lucas, purchased two undeveloped waterfront lots on the Isle of the Palms, a breaker island near Charleston, South Carolina. The combined purchase price for the two lots was $\$ 975,000$. Lucas intended to develop one lot for his personal use and to hold the other for investment purposes. At the time of purchase, the land was zoned for single family development, and a similar house had already been built on the lot that lay between Lucas' two lots. However, before any construction could begin on Lucas' lot, South Carolina passed the Beachfront Management Act (BMA) ${ }^{13}$ which, effective July 1, 1988, prohibited virtually all new construction between the beach and certain setback lines. ${ }^{14}$ Under the new ordinance, Lucas was unable to build on either of his lots. In his action for compensation, Lucas claimed that the property in question had been deprived of all its economic value. He further argued that the property in fact had a negative value to him because the allowable uses under the BMA - tenting, recreation, or using the site for a removable mobile homewere worth less than the costs of the real estate taxes and liability insurance associated with owning the land. ${ }^{15}$ Though the Coastal Council contested both of Lucas' claims, the trial judge held that the regulation constituted a "total taking" of Lucas' two lots. ${ }^{16}$ Accordingly, he issued an order with two provisions. First, Lucas was instructed to convey title of the property to the state of South Carolina free and clear of the mortgages used to purchase it. Second, the judge ordered the State to pay Lucas market value for the property and to return any property taxes collected after the effective date of the Coastal ordinance. ${ }^{17}$

For my own criticism on the conflation of notice with waiver and assumption of risk, see EPSTEIN, TAKINGS, supra note 5 , at 151-58.

13. S.C. CODE ANN. $\S \S 48-39-10$ to $48-39-360$ (Law. Co-op. Supp. 1992).

14. Id. \$ 48-39-290.

15. Amicus Curiae Brief, supra note 5 , at 1238 (citing Trial Transcript at 31).

16. Order of Trial Judge at 130 . That finding was accepted by Justice Scalia, Lucas, $112 \mathrm{~S}$. Ct. at $2894 \mathrm{n.7}$, and is presumably binding on the remand of the case.

17. Order of Trial Judge at 130. 
The South Carolina Supreme Court reversed the trial court's decision, noting that at trial Lucas had failed to address South Carolina's justifications for the regulations in question. ${ }^{18}$ That omission was deemed fatal for Lucas, as it amounted to a concession that the dunes on which he wished to build were indeed a fragile resource and that the regulation was necessary to prevent serious public harm. Having conceded to the state's assertions, the court found that the regulations thus fell securely within the ambit of the police power as it had been analyzed in earlier cases under the Takings Clause. ${ }^{19}$

\section{B. Reasonable Expectations and the Definition of a Taking}

Before Lucas reached the Supreme Court, the South Carolina legislature had modified the BMA to allow "special permits" for construction of habitable structures on the seaward side of the setback line. South Carolina contended that Lucas no longer presented a total taking case. ${ }^{20}$ The United States Supreme Court disposed of this argument on two grounds. First, it found that although the issue had been alive at the state court level, it had not been relied on by the court. Second, it found that Lucas nonetheless could still have a claim for a total interim taking, compensable under First English Evangelical Lutheran Church v. County of Los Angeles. ${ }^{21}$ Thereafter, the Court turned to the merits, where the question of reasonable expectations surged to the foreground as the Court struggled to unsnarl the tangled web of its takings doctrine.

Justice Scalia begins his analysis with the observation that permanent physical takings of land normally require just compensation "no matter how weighty the public purpose behind [the state's regulation]."22 On the other

18. Lucas v. South Carolina Coastal Council, 304 S.C. 376, 404 S.E.2d 895, 896-98 (1991), rev'd and remanded, $112 \mathrm{~S}$. Ct. 2886 (1992). The state's justifications were set out in broad terms in S.C. CODE ANN. $\S \S 48-39-30$ \& 48-39-260 (Law Co-op. Supp. 1992), and included arguments that legislation was necessary to protect the beach/dune system from erosion and other environmental hazards, to provide habitat for plants and animals, to promote tourism in the state, and to assure a natural, healthy environment for the leisure time activities of the citizens of South Carolina. There was no effort to disentangle police power from public use justifications, even though the former allow regulation without compensation, while the latter do not. See Amicus Curiae Brief, supra note 5, at 1241-43.

19. Lucas, 404 S.E.2d at 900 ('Lucas fails to attack in any way the legislature's 'findings' that new construction would cause serious public harm. This amounts to a concession that the Mugler 'nuisance-like exception' applies.'). The reference is to Mugler v. Kansas, 123 U.S. 623 (1887), which announced the police power exception to the Takings Clause and applied it to regulations on the manufacture and sale of intoxicating liquor.

20. Lucas, 112 S. Ct. at 2890-91 (citing S.C. CODE ANN. \$ 48-39-290(D)(1) (Law. Co-op. Supp. 1990)). The point was urged in Justice Blackmun's dissent. Id. at 2907 (Blackmun, J., dissenting).

21. 482 U.S. 304, 321 (1987) (holding that temporary deprivations of use are compensable under the Takings Clause) (cited in Lucas, $112 \mathrm{~S}$. Ct. at 2890-92).

22. Lucas, $112 \mathrm{~S}$. Ct. at 2893 . Scalia cites three cases where a taking was found: Loretto v. Teleprompter Manhattan CATV Corp., 458 U.S. 419 (1982) (holding that a statute requiring landlords to allow CATV hookup on property, occupying about 1 and $1 / 2$ cubic feet, mandated compensation); Kaiser Aetna v. United States, 444 U.S. 164 (1979) (holding a public easement of navigation over private waters to be a taking); and United States v. Causby, 328 U.S. 256 (1946) (finding that 
hand, land use regulations that deprive the land of some or all of its economically beneficial use are subject to far less exacting constitutional review than are physical takings. Only if a land use regulation "does not substantially advance legitimate state interests or denies an owner economically viable use of his land" will it be invalidated. ${ }^{23}$ The question is why the boundary line between compensable and noncompensable land use regulations is drawn to distinguish total from partial takings, as well as the physical from the regulatory.

Justice Scalia mentions two other hardy standbys in the takings literature. First, he notes that complete loss of economic use may well be regarded as the "equivalent of a physical appropriation."24 Yet he never addresses, let alone answers, the looming question of why a partial restriction on land use is not similarly treated. A partial restriction that tracks in content a private restrictive covenant on land use should be regarded as the equivalent of a partial physical appropriation, and thus compensable under the Takings Clause. ${ }^{25}$

\section{Justice Scalia's second argument is also familiar:}

Surely, at least, in the extraordinary circumstance when no productive or economically beneficial use of land is permitted, it is less realistic to indulge our usual assumption that the legislature is simply "adjusting the benefits and burdens of economic life" in a manner that secures an "average reciprocity of advantage ..."26

The obvious rejoinder is to ask why the Court should ever "indulge" an assumption that this average reciprocity of advantage normally will apply, in light of the enormous political pressures from both minority factions and determined majorities that so often lead legislatures astray. To the extent that there is average reciprocity of advantage in a given statute, there is greater reason to believe that the legislation will produce improvements in overall social welfare. ${ }^{27}$ Even so, the average reciprocity of advantage in each case should be established by the evidence, rather than presumed as a matter of law. Why assume that partial restrictions are motivated by high public purpose but that total restrictions are not?

overflights that are so low as to interfere directly and immediately with the enjoyment and use of the land below constitute a taking).

23. Lucas, 112 S. Ct. at 2894 (quoting Agins v. City of Tiburon, 447 U.S. 255, 260 (1980)) (emphasis omitted).

24. Id.

25. If a person owns a restrictive covenant on land that has been condemned by the government, it is undisputed that there has been a taking of property. This situation arises frequently, for example, when a plot of land subject to a covenant is taken for a particular public use that is inconsistent with the interests of the covenantee. See, e.g., Southern Cal. Edison Co. v. Bourgerie, $9 \mathrm{Cal}$. 3d 169, 507 P.2d 964, 107 Cal. Rptr. 76 (1973). Logically, the same property rights have been infringed when the government imposes a covenant on land that was previously unencumbered, which is what zoning does. In the one case it takes an interest that has already been made discrete, while in the second it simply takes the same discrete part of a larger whole.

26. Lucas, 112 S. Ct. at 2894 (quoting Penn Cent. Transp. Co. v. New York City, 438 U.S. 104, 124 (1978) and Pennsylvania Coal Co. v. Mahon, 260 U.S. 393, 415 (1922) respectively).

27. EPSTEIN, TAKINGS, supra note 5 , at 195-215. 
Justice Scalia has the good sense to be uneasy about his own explanations for the traditional rule. Addressing one of its most important theoretical weaknesses, he notes:

[This] rule does not make clear the "property interest" against which the loss of value is to be measured. When, for example, a regulation requires a developer to leave $90 \%$ of a rural tract in its natural state, it is unclear whether we would analyze the situation as one in which the owner has been deprived of all economically beneficial use of the burdened portion of the tract, or as one in which the owner has suffered a mere diminution in value of the tract as a whole.... Unsurprisingly, this uncertainty regarding the denominator in our "deprivation" fraction has produced inconsistent pronouncements by the Court.... The answer to this difficult question may lie in how the owner's reasonable expectations have been shaped by the State's law of property-i.e., whether and to what degree the State's law has accorded legal recognition and protection to the particular interest in land with respect to which the takings claimant alleges a diminution in (or elimination of) value. In any event we avoid this difficulty in the present case, since the "interest in land" that Lucas has pleaded (a fee simple interest) is an estate with a rich tradition of protection at common law, and since the South Carolina Court of Common Pleas found that the Beachfront Management Act left each of Lucas's beachfront lots without economic value. ${ }^{28}$

This passage, devoid of legal theory, exposes the poverty of the "reasonable expectations" language as construed by Justice Scalia. The initial situation to which Justice Scalia alludes-the question of whether a certain regulation is a partial restriction on the whole parcel, or a total restriction on part of the parcel-may not have been presented by the facts of Lucas. But it is surely the next issue in the development of a comprehensive theory of the Takings Clause. Often the common law wisely proceeds incrementally, and the open-ended nature of the Eminent Domain Clause invites the Court to create a system of constitutional common law that is equally slow moving. It is one thing to issue restrained utterances when it is not clear what lies ahead; it is quite another to practice evasion in the name of cautious decisionmaking. As Justice Scalia himself notes, the issue of partial restrictions on land use looms, unresolved, on the horizon. Any theory of regulatory takings that openly confesses its inability to come to grips with that issue is dead before it is born. And when the theory fails, so does its foundational principle of reasonable expectations.

As I have argued on other occasions, ${ }^{29}$ Justice Scalia's great intellectual mistake is to assume that the "deprivation' fraction" is the appropriate way to look at takings problems. The initial problem with his approach is that it leads to massive doctrinal discontinuities. Justice Scalia acknowledges the difficulty when he writes:

It is true that in at least some cases the landowner with $95 \%$ loss will get

28. Lucas, 112 S. Ct. at 2894 n.7 (citations omitted).

29. See Amicus Curiae Brief, supra note 5, at 1242-43; Richard A. Epstein, Takings: Descent and Resurrection, 1987 SuP. CT. REV. 1, 16-17. 
nothing, while the landowner with total loss will recover in full. But that occasional result is no more strange than the gross disparity between the landowner whose premises are taken for a highway (who recovers in full) and the landowner whose property is reduced to $5 \%$ of its former value by the highway (who recovers nothing). Takings law is full of these "all-ornothing" situations. ${ }^{30}$

His feeble response reflects his flawed methodology. Initially, he does not understand the enormous difference between his two hypotheticals. Physical condemnation of land for a highway is a taking in the traditional sense of that term, whereas construction of a new highway elsewhere in town is merely a form of competition against which no landowner is ever entitled to compensation. The analysis is quite different when barricades are erected to block access to the road, creating a situation in which compensation is required. The key difference between these two cases is not the level of the reduction in value. Rather, it is the means used to achieve the reduction. Simply to observe that government action results in a reduction in property value is to avoid the critical middle step of the analysis, which asks whether there was a taking of property that makes the loss compensable in the first instance. ${ }^{31}$ There is a broad class of actions that are damnum absque injuria (harm without legal injury) at common law, of which competition is perhaps the most important illustration. The same idea applies in the law of eminent domain. The reductions in value are thus, by themselves, irrelevant to the overall analysis.

Justice Scalia's analysis fares no better when applied to partial takings. Under his analysis, where the owner acquires a single large plot from one source, any inquiry into the fraction taken and the fraction retained may yield one result - a noncompensable taking-because the taking is now considered partial. Magically, the same taking would likely be compensated if the land had been acquired from two separate owners, especially if it has a fence along the boundary.

However, "reasonable expectations" cannot make the level of constitutional protection turn on whether title is registered in one deed or two, whether the property was acquired from one transferor or two, or whether it was acquired at one time or two. Protection should only depend on the property one owns, not how it was acquired, be it by grant, original occupation or even adverse possession. Only one thing is relevant: The greater the taking, the greater the payment. What is taken is what counts; what is retained, or the ratio between retained and taken property, is irrelevant (except for determining any potential severance damages). ${ }^{32}$ Under this approach, all the discontinuities are eliminated, and the line between total and partial

30. Lucas, 112 S. Ct. at 2895 n.8.

31. For discussion, see Epstein, TAKINGs, supra note 5, at 77-80.

32. The movements can be in either direction. For example, when a strip of land is taken for a highway, the value of the retained portion will increase if the value of improved access to the road exceeds the discomfort from traffic noise. If the numbers are reversed, however, then severance damages should be awarded. There is no a priori way to decide which state of affairs holds without looking at the evidence. 
takings is relevant only to the question of how much compensation is required, not to whether there is a basic obligation to compensate.

Justice Scalia's odd approach to reasonable expectations is at war with the ordinary meaning of the Fifth Amendment, and bears no relation to any theory of original intent of the sort that he himself champions. ${ }^{33}$ The notion of reasonable expectations is unrelated to any useful inquiry about the function of the Takings Clause. Moreover, Justice Scalia's approach invites the form of governmental abuse that the Bill of Rights was designed to control. For instance, once the Court lets it be known that a value deprivation of 95 percent requires no compensation, what legislature will be foolish enough to take an entire plot of land? Consequently, the Court has provided an effective blueprint for confiscation that budget-conscious state legislators will be eager to follow to the letter. His "occasional result" will become the constitutional norm: Partial takings, such as those effected by the "special permit provisions" of the 1990 Amendments to the BMA, though virtually total in their form, will remain uncompensated.

\section{Reasonable Expectations and the Nuisance Exception}

The second portion of Justice Scalia's opinion addresses whether the state has any justification for the takings that it imposes. Both Lucas and the Coastal Council tried to avoid entirely this side of nuisance law in their arguments. Lucas advanced the wholly untenable theory that if the taking were total, then the question of state justification would be irrelevant. On the other hand, the Coastal Council argued that if Lucas conceded that "great public harm" existed, then he had conceded as well that his proposed development created the kind of nuisance or noxious use that could be banned under the police power. ${ }^{34}$

Justice Scalia rightly refused to entertain the plaintiff's exotic theory. By the same token, however, he refused to allow the state to evade the serious substantive issues by hiding behind the plaintiff's alleged strategic mistake at the trial level. Charting his own course, Scalia sought to add substance to the police power exception beyond saying that it allowed the state to control common law nuisances or noxious uses of property. Justice Scalia was obviously uncomfortable with this formulation; like most judges, even those broadly supportive of property rights, ${ }^{35}$ he is deeply suspicious of linking constitutional rights with common law notions of property and freedom of contract. In his haste to divorce himself, in part, from the common law tradition, Justice Scalia reformulates the doctrine: The police power is not confined to cases of nuisance or noxious use, but extends to any other form of regulation that advances a "legitimate state interest."

33. See Antonin Scalia, Originalism: The Lesser Evil, 57 U. CIN. L. REv. 849 (1989).

34. The South Carolina Supreme Court accepted the Council's argument on this point. See Lucas, 112 S. Ct. at 2896-97.

35. For an example of a judge who is also supportive of property rights, see $i d$. at 2903 (Kennedy, J., concurring). 
As Justice Scalia admits, he is unable to make peace with the distinction between a "harm-preventing" and a "benefit-conferring" regulation (which is the traditional analysis used to distinguish nuisance from nonnuisance regulations). For Justice Scalia, the distinction is too often "in the eye of the beholder." 36 "One could say that imposing a servitude on Lucas's land is necessary in order to prevent his use of it from 'harming' South Carolina's ecological resources; or, instead, in order to achieve the 'benefits' of an ecological preserve." 37 Faced with the inadequacy of the distinction, Justice Scalia resorts to reasonable expectations, rather than the definition of nuisance, to define the limits of the police power:

Where the State seeks to sustain regulation that deprives land of all economically beneficial use, we think it may resist compensation only if the logically antecedent inquiry into the nature of the owner's estate shows that the proscribed use interests were not part of his title to begin with. This accords, we think, with our "takings" jurisprudence, which has traditionally been guided by the understandings of our citizens regarding the content of, and the State's power over, the "bundle of rights" that they acquire when they obtain title to property. It seems to us that the property owner necessarily expects the uses of his property to be restricted, from time to time, by various measures newly enacted by the State in legitimate exercise of its police powers; "[a]s long recognized, some values are enjoyed under an implied limitation and must yield to the police power."38

As before, Justice Scalia's effort at generalization obscures all the relevant issues. The language of noxious use and nuisance purports to offer some operational content to the police power conception, while the use of "legitimate" state interests removes all empirical content from the police power justification. His reliance on popular understandings of property rights fails to explain what reasonable expectations are; indeed, there is no reason to believe that they are uniform across broad sectors of the population. And surely, building a single-family home on private land falls into the ordinary set of expectations unless some justification (i.e., a nuisance) for such a limitation is offered-and none is. Furthermore, it cannot be said that the old nuisance and noxious use language has been banished from the discourse. Surely, any state regulation that can offer these justifications is manifestly constitutional - a result that is possible only because the difference between harm prevention and benefit creation is easily discernable (the difference between the law of tort and the law of restitution, no less) from countless cases involving the control of toxic wastes and air and water pollution. Thus Justice Scalia's linguistic skepticism is misplaced, as it is in any serious intellectual inquiry. To his credit, he eventually reverts to the nuisance language, but only after a long detour through the reasonable expectations maze:

36. Id. at 2897 .

37. Id. at 2898.

38. Id. at 2899 (quoting Pennsylvania Coal Co. v. Mahon, 260 U.S. 393, 413 (1922)) (footnote omitted). 
We believe similar treatment [to physical takings] must be accorded confiscatory regulations, i.e., regulations that prohibit all economically beneficial use of land: Any limitation so severe cannot be newly legislated or decreed (without compensation), but must inhere in the title itself, in the restrictions that background principles of the State's law of property and nuisance already place upon land ownership. A law or decree with such an effect must, in other words, do no more than duplicate the result that could have been achieved in the courts-by adjacent landowners (or other uniquely affected persons) under the State's law of private nuisance, or by the State under its complementary power to abate nuisances that affect the public generally, or otherwise. ${ }^{39}$

Justice Scalia does not explain why his approach is workable only for regulations that prohibit all economically beneficial use of land, or why this approach is congruent with the question of reasonable expectations. In the end, his views can be defended largely on the ground to which he refers in the last quoted sentence: Namely, the relationship between private and state disputes. ${ }^{40}$ This defense suggests a far closer unity between private and public law than Justice Scalia previously acknowledged. Therefore Part II will depart from constitutional law for a moment, and analyze briefly the uses and pitfalls of the conception of reasonable expectations (and its verbal variations) in the private law.

\section{Reasonable Expectations in Private LaW}

The troubled connection between expectations and entitlements that plagues Justice Scalia's analysis in Lucas should come as no surprise to anyone who has attempted to resolve the complex set of legal rules governing private disputes-that is, those involving ordinary people not invested with the special power of the state. The term "expectations" is used in such varied senses in private law that it is possible to posit virtually any relationship between expectations and entitlements. In some situations, an expectation is considered the antithesis of a property right; in others, expectation appears to be the basis of the property right. In still other cases, expectations seem to embody property rights. In most situations, the ubiquity and variability of the concept does not cause undue practical damage because the context makes the relationship clear. A brief detour into the role of reasonable expectations in the private law, however, should provide some clue as to why and how the concept must be refurbished if it is to bear the heavy weight that Justice Scalia places on it in both halves of his analysis.

39. Id. at 2900 . In a related footnote, Scalia rightly gives a narrow reading to the term "otherwise," to cases of "actual" (or public) necessity, such as the destruction of property to prevent a fire or to forestall other grave threats to the safety of the public at large. Id. at 2900 n.16. For a similar gloss on the nuisance prevention rationale, see Epstein, Ruminations, supra note 5, at 1228-29.

40. For similar arguments, see Amicus Curiae Brief, supra note 5, at 1244-48; EPSTEIN, TAKINGS, supra note 5 , at 349-50. 


\section{A. Explicit Expectations}

In private law contexts, the parties are often explicit about whether or not an expectation will be protected by a legal remedy. If so, then there is a right; if not, there is none. This approach is often adopted in well-drafted trust instruments, which specify whether a stream of future payments is precarious in the beneficiary or whether it is protected. Where protected, a property right exists. However, if the payments are precarious in the beneficiary, no property right exists, merely powerful social expectations that certain customary results will follow. These planned expectations are not without their uses. While the expectation that a child has under a vill, a revocable inter vivos trust, or even the laws of inheritance can be dashed without recourse, it is highly unlikely that this will ever happen (which is why we call it an "expectation" to begin with). In most cases people are sufficiently confident that their expectations will be fulfilled that they alter their behavior to account for the anticipated benefit. But if the expectation fails, no legal recourse exists, because no property right exists.

Of course, some property interests protected under law may never materialize. For instance, the common law has historically distinguished between contingent and vested remainders. The distinction is that contingent remainders are subject to conditions, and thus might never become possessory, while vested remainders presumably will. ${ }^{41}$ But even contingent remainders are "vested" in the sense that no private party can simply choose to ignore them if they vest. Similarly, the government must pay just compensation when it takes a contingent remainder, just as it does when it takes any other property interest. ${ }^{42}$ The contingent remainder thus has elements of both mere expectation and protected right, and their mixed nature should be respected on all occasions, both public and private.

Nonetheless, it is easy to disregard these expectations in cases where they are not, in some sense, settled or protected. For example, in Spirt v. Teachers Insurance \& Annuity Ass'n (TIAA), ${ }^{43}$ sex-based annuity tables used by TIAA were struck down as a violation of Title VII on the ground that they discriminated against women. In response to the claim, TIAA argued that any alteration in the rules by which annuities were calculated would violate the settled expectations of the male annuitants. The Second Circuit responded, in part, that the only amounts guaranteed under the TIAA plans reflected a 2.5 percent rate of return; consequently, any additional sums based on higher market yields were not "settled" expectations. ${ }^{44}$ Likewise, since contributions to the equity fund had no minimum floor at all, these expectations were also considered too diffuse to be settled.

41. The "presumably" is necessary because some vested remainders (e.g., a vested life estate in remainder) may never become possessory. This particular estate is treated as vested for historical reasons.

42. See, e.g., Ink v. City of Canton, 4 Ohio St. 2d 51, 212 N.E.2d 574 (1965) (discussing the evaluation of a possibility of reverter in a takings case).

43. 691 F.2d 1054 (2d Cir. 1982), vacated, 463 U.S. 1223 (1983).

44. Id. at $1068-69$. 
The argument in Spirt rests on the same equivocation in the idea of expectation developed above. The original promise to all members of the TIAA was that a certain formula would be used to calculate their return. Individual members of the plan thus assumed the risk of fluctuation in the rates of return, while being guaranteed the minimum protection of the formula. The court's decision conflated the two matters by stripping persons of the protection of the formula because the amounts of cash it yielded were subject to market fluctuation. This treatment of expectations thus sidestepped a claim that the retroactive nullification of the formula impaired the obligation of contract in violation of the Contracts Clause. ${ }^{45}$ But the analysis is unpersuasive. Indeed, the cavalier attitude of Spirt toward expectations suggests that if the state decided to take all returns above any guaranteed minimum and place them into the public treasury, no TIAA member could complain about the loss of property rights.

Expectations play a role in employment as well as financial contexts. Often (in the days before regulation) employers would formally insist that a contract be at-will, even though the informal expectation is that dismissal will occur only for good cause. The divergence between the formal contract and the informal expectation is created because the legal remedy is thought to present greater social cost and uncertainty than the unfettered private action of the employer limited only by informal norms and reputational constraints. The employee has no property interest in continued employment because there was no intention to create it as such. The connection between property and expectation is clearly defined by the applicable agreement or the relevant rule of substantive law.

\section{B. Implicit Expectations}

Determining the relationship between expectations and property rights is more difficult in the absence of any authoritative pronouncement on the subject. The question of expectations is intimately tied to the choice of the appropriate default rule, which is often intended to replicate the reasonable expectations of the parties. The problem here is identical to that raised by Justice Kennedy in the constitutional context: How is it possible to invoke the doctrine without falling prey to circularity? That question is difficult to answer in the round, but perhaps it is instructive to give two illustrations of the problem from the private law: The expectation measure of damages in the law of contracts, and the reasonable expectations doctrine in the law of product liability.

\section{The expectation measure of contract damages.}

Under the common formulation of the expectation rule of damages, the nonbreaching party is entitled to recover from the party in breach a sum of money that leaves him indifferent between performance and breach. ${ }^{46}$ The

45. See, e.g., Allied Structural Steel Co. v Spannaus, 438 U.S. 234 (1978).

46. See, e.g., E. Allan FarnSwORTH, ConTracts $\S \S 12.8-12.10$ (2d ed. 1990). 
measure of damages gives the party what was "expected" from the undertaking ex ante. The theory behind expectation damages is often termed "efficient breach." 47 So long as the innocent party is left indifferent between breach and performance, any decision to breach will produce a Pareto improvement. The breaching party will breach only if the damages paid are less than the gains obtained from the breach. The breaching party will be better off, while the innocent party is not made worse off, producing a net social improvement.

This theory is subject to a number of powerful objections, not the least of which is that expectation damages are often difficult to calculate. They can provide insufficient compensation if certain elements of damages are speculative or hard to assess. Moreover, this method can lead to overcompensation by reducing the incentives that nonbreaching parties have to mitigate loss, or more generally, by inducing an excessive level of reliance on a contract promise.

The weaknesses of expectations as a measure of damages illustrate the difficulty of translating economic expectation into legal entitlement. The reason the expectations measure deserves its dominant position is that, at least in some contexts, it promises the maximum gain to the parties ex ante. This is typically the case where the contract is for the sale of stock or property, and the breach leaves the breaching party in possession of the thing sold. There are many settings, however, where the expectation measure of damages does not comport with the expectations of the parties, as evidenced by their preference for some other damage rule which better serves their joint needs (for example, liquidated damages) ${ }^{48}$ Consequently, it should not be assumed, in the tradition of Lon Fuller, that the expectation measure of damages represents some ideal, from which all deviation is suspect. ${ }^{49}$ Rather, conventional expectation damages form the appropriate default rule only when they, and not an alternative measure such as reliance or restitution, maximize the positions of both parties ex ante. The prediction of a nonbreaching party of $\mathrm{X}$ gain from performance is not the same as a contractual entitlement for the payment of $X$ damages in the event of breach. Discerning the gap between the predictive and the normative is necessary to make sense of this area of the law.

\section{Consumer expectations.}

A parallel argument applies in product liability cases, which rest, in fact, on an amalgam of tort and contract principles. In such cases it is often said that whether a product is defective depends on whether it meets with consumer's expectations. The most well-known statement of this position is found in the Restatement (Second) of Torts, which explains that a product is

47. See, e.g., Daniel Friedmann, The Efficient Breach Fallacy, 18 J. LEGAL STUd. 1 (1989).

48. For the variations of this sort, see Richard A. Epstein, Beyond Foreseeability: Consequential Damages in the Law of Contract, 18 J. LEGAL STUD. 105 (1989).

49. L.L. Fuller \& William R. Perdue, Jr., The Reliance Interest in Contract Damages: 1, at 46 YALE L.J. 52 (1936). 
considered defective for strict liability purposes "only where the product is, at the time it leaves the seller's hands, in a condition not contemplated by the ultimate consumer, which will be unreasonably dangerous to him."so The effort to make that standard the linchpin of product liability law has, however, foundered, for the case law has

flatly rejected the suggestion that recovery in a products liability action should be permitted only if a product is more dangerous than contemplated by the average consumer, refusing to permit the low esteem in which the public might hold a dangerous product to diminish the manufacturer's responsibility for injuries caused by that product. ${ }^{51}$

The difficulties introduced to the law of product liability by this and similar sentences have not been untangled in the fifteen years since they were first written. Once courts rejected consumer expectations as the basis of liability, they turned to elaborate cost/benefit analyses of product designs that (at least before accidents) conform to no one's expectations. The law started down that slippery path because judges failed to understand the proper uses and inherent limitations of the expectations principle in product liability law, or, in contract law more generally. Expectations are not set in contract simply by asking whether one expects, i.e. predicts, good or bad things to happen from the use of a particular product. The key question is not whether both sides expect that accidents are more likely to occur when products are made in a shoddier fashion. Both parties will know the truth of that proposition; thus the common knowledge does little to allocate or apportion the loss between them.

How then is the allocation made? In the easier case it is made by an explicit allocation, which, if respected, makes this issue identical to the more traditional trust and wills questions above. But more often, the parties are silent, and the question of allocation must be resolved when both parties suspect that something could go wrong. In the absence of good information, one could use the allocation that maximizes the joint utility of the parties ex ante, as that is the kind of global expectation desired by all parties. In my view, that allocation process is usually one that follows the common law axiom that parties are responsible in damages for misrepresentations of the products they sell, but are not responsible for conditions known to the buyer, because they are obvious, they are subject to common knowledge (like the properties of alcohol or tobacco), or they have been disclosed.

In this legal universe, the hypothetical difficulty raised in the previous paragraph disappears. If the defects are latent, then the product is of lower quality, injury is more likely to occur, and the defendant bears greater liability. The "low esteem" in which the product is held is a function of an implicit misrepresentation, so that the basis of liability need not depend on any

50. Restatement (SECOND) of TORTS $\S 402 \mathrm{~A} \mathrm{cmt}$. g (1964).

51. Barker v. Lull Eng'g Co., 20 Cal. 3d 413, 425, 573 P.2d 443, 451, 143 Cal. Rptr. 225, 233 (1978). On Barker's cost/benefit formula, see Richard A. Epstein, The Risks of Risk/Utility, 48 OHro ST. L.J. 469 (1987) (criticizing Wade); John W. Wade, On the Nature of Strict Tort Liability for Products, 44 Miss. L.J. 825 (1973). 
product-specific judgment, but on the basic social norm that attaches legal sanctions to misrepresentations in general. But where the defect is obvious in any of the senses mentioned above, then the buyer or user takes it at his own risk, as again through a general norm, unless there is some express warranty to displace that proposition. ${ }^{52} \mathrm{~A}$ manufacturer may very well be held in low esteem by consumers generally, but so long as the defects are latent, the ordinary action is allowed. On the other hand, if the defects are patent, then the ability to make a sale (which is incorrectly taken as a constant in Barker) will be compromised as consumers will adjust their expectations and behavior to account for the greater risk of loss. The rule of consumer expectations therefore should not be regarded as saying that manufacturers with worse reputations are subject to lesser liability. It should be understood as making an explicit distinction between those risks that are known and those that are assumed-knowledge of risk is not the same as assumption of risk. The latter connotes the acceptance of the loss and the waiver of the right of action. The former indicates only that the consumer knew of the potential for loss, but maintained the right of action.

The same pattern of argument appears in the context of product misuse. Here it is possible to craft a theory of reasonable expectations that renders the entire theory vacuous. It is clear that users and consumers could reasonably expect manufacturers to supply shoddy products, and hence waive all rights of action with purchase. It could follow that consumers use all products at their own peril, thus providing the crudest measure of product liability reform. Yet, by the same token, it is possible for manufacturers reasonably to expect that consumers and users will disregard instructions and misuse their products. From that it could follow, as the doctrine of "reasonably foreseeable misuse" all too often implies, ${ }^{33}$ that the defendant should always be held responsible no matter what the plaintiff has done. The same analytical tool thus points in opposite directions: universal liability and universal exculpation. These positions cannot both be correct, but they can both be wrong, and are.

The source of the error again lies in the effort to avoid the principle of optimization. Because both extreme rules invite severe misbehavior, albeit from opposite directions, neither promotes optimality. To be sure, any effort to compromise always involves implicit trade-offs, for as defenses are strengthened, the defendant's initial obligation is weakened, and vice versa. But if the cost of what is surrendered is less than what is gained, then an effective compromise can be reached. The early product liability cases, even after the adoption of the principle of strict liability, did adopt an intermediate position on the question of plaintiff's misconduct. The plaintiff could recover only if he put the product to a "normal and proper" or "intended"

52. See U.C.C. $\S 2-313$ (1989), for the evident tensions in determining what behavior by a seller is sufficient to set up an express warranty.

53. See, e.g., LeBouef v. Goodyear Tire \& Rubber Co., 623 F.2d 985, 989 (5th Cir. 1980) (allowing recovery under the forseeable misuse test where plaintiff's tire tread separated from the tire while he was driving, drunk, at 100 to 105 miles per hour on standard tires). 
use. This formula uses expectations in a very different way by presupposing that the plaintiff can infer what uses of a product are expected from general acquaintance with the product itself. It further presupposes that consumers and manufacturers would, ex ante, opt for the same division of risk. If the total cost of accidents (prevention plus losses) are lower in this formulation than in either of the extremes, then this rule meets a set of reasonable expectations that both parties should respect.

\section{Ambiguous EXPECtations in Modern TAKings LAw}

The stage is now set for understanding the uses and misuses of reasonable expectations in takings law. As before, there are two possible ways to understand reasonable expectations. The first is to ask parties to make predictions about how others will act, without inquiring whether the rules so created will induce proper conduct by all parties to any potential conflict. Although one landowner knows that his neighbor previously has polluted air and water, the reasonable expectation that these forms of conduct will reoccur hardly amounts to a compensation-barring assumption of the risk. The rule holding the pollutant liable for his activity promises greater joint wealth (or utility) for the parties than the alternative rule, which tolerates unlimited levels of pollution. In order to obtain the right to pollute neighboring lands, the far more exacting requirements for prescriptive easements must be satisfied, including continuous and open pollution over long periods of time without permission from the neighboring landowner.

Similarly, a landowner's predictions of impending regulation hardly amount to an acceptance of the risk of the economic consequences. It is commonly said that the pervasive nature of uncompensated government regulation of land use leads landowners to expect further regulation. ${ }^{54}$ Yet this proposition does not explain how the regulatory practice began in the first place. Consider the first bit of land use regulation that imposes a street setback regulation of ten feet. When challenged on constitutional grounds, the usual arguments will call for some comparison between private cost and public benefit. The trifling nature of the regulatory interference will constitute one of the strongest arguments for upholding the law. But suppose now that the first round of regulation clears the path for sustaining the constitutionality of a second, more intrusive regulation. If initial regulation at once anticipates more to come, it is then incorrect for the state to balance only the cost of upholding the initial regulation (which may only minimally affect private interests), for now the government's success in the initial foray increases its ability to enact subsequent, more restrictive regulations without

54. See, e.g., Prah v. Maretti, 108 Wis. 2d 223, 236, 321 N.W.2d, 182, 189 (1982) (listing among its justifications for creating solar easements that society has "increasingly regulated the use of land by the landowner for the general welfare"). In fact, solar easements have precisely the opposite effect, especially where they are imposed between neighbors whose relations are already regulated by a subdivision easement explicitly addressing the distance of any structure from the boundary line. The common subdivision agreement removes any prospect of negative externalities that might otherwise justify creating a liability for a physically noninvasive nuisance. 
violating private expectations. After all, if the initial regulation is held constitutional, then it is foreseeable that a more stringent one will be sustained. The state will be able to argue for increasingly invasive regulations on the basis of the constitutionality of the prior ones. Adopting any intermediate position on the limits of the state power becomes unrealistic if the knowledge of the regulated landowner is sufficient to imply his expectation of future government regulation. This analysis leads us, inexorably, to the state's position in Lucas - that if some land use regulation creates the expectation of more regulation, then all land use regulation is constitutional. Strategically, astute counsel for the government should initially deny the far-reaching implications of this position. Only later will the state's forensic position shift. Yet the game can be understood by the other side as well, so that it no longer is possible to litigate the first land use regulation without looking over the shoulder at all that might follow. There is no reason to allow the imported idea "reasonable expectations" to divert the Takings Clause from its original purpose. The only expectation that the Framers held when they drafted the Clause was that government would conform its behavior to the requirements of the Takings Clause, whatever those turned out to be. There is no reason to allow a fictional gloss of reasonable expectations to take on a life of its own, where it will necessarily dilute the protection to private property that the constitutional text explicitly provides.

Once the fashionable underbrush is cleared away, we are still left to determine which expectations should inform constitutional discourse. To do that, we must understand the relationships created by private property not only between the property and its owner, but also between the owner and the rest of the world. In the property context, the task is more complex than in the cases of contractual expectations discussed above, as the parties have no ongoing relationship to help them tease out their optimal arrangement. But the same general principles still apply: Reasonable expectations must be used to define the relationship between strangers in ways that maximize their joint welfare, a task which requires a number of steps. First, a framework of basic reciprocity must be adopted in which neither side could claim any special advantage denied to the other. But merely adopting a condition of equal right does not specify what substantive rights should be held equal; the best procedure for determining the content of those rights is to search for the rule that will maximize joint welfare. Thus the equality constraint is consistent with a world in which no one can develop property, as well as one in which each person can do whatever he wants with his own property-extremes that are not dissimilar to those rejected in the product liability area. The baseline that allows all use of property is surely a better starting point than the alternative that allows none. In most cases, the right to use one's own land freely is more important than the right to veto one's neighbor's use of his land.

The initial presumption of unrestricted property rights is only the first of successive approximations. The question then arises of how land use might thereafter be limited. One obvious device is regulation by restrictive cove- 
nant, binding on both parties to the initial land transfer and their successors in title, where notice has been filed. ${ }^{55}$ Indeed, most restrictions on land use are a product of private arrangements, such as real covenants. For some class of uses, the value of use may be greater than the value of enjoining use by neighbors. But for other proposed uses, the balance of convenience could produce the opposite result. In practice, most restrictive covenants involve a mutual exchange of restrictions rather than an exchange of a restriction for cash. Most critical to Lucas, any effort in the private arena to draw the categorical distinction between total and partial restrictions on use is fruitless. Restrictive covenants are frequently partial; but whether partial or total, they are acquired by consent rather than coercion. Any alternative system that allows one person to impose restrictions on the land use of others without compensation will engender the forms of strategic behavior that threaten to destroy any social fabric. One landowner could insist that his neighbor build only houses costing more than one million dollars, while another could insist that neighboring houses be unobservable from the road, and so on. The joint value of two neighboring plots under this regime could quite easily be made negligible, and an increase in the number of the parties included in the arrangement hardly improves matters. There are now more persons who could be done in by overzealous neighbors. Under the traditional private law regime, restrictions on use could only be imposed by consent.

The law of eminent domain dispenses with the need for consent when the taking is for a public use, for which public leisure and aesthetic pleasure surely qualify. But where the taking goes forward, the law of takings does not dispense with the need for compensation. Justice Scalia identified the crucial point when he stated, in a sentence that bears repetition, that

[a] law or decree with such an effect must, in other words, do no more than duplicate the result that could have been achieved in the courts-by adjacent landowners (or other uniquely affected persons) under the State's law of private nuisance, or by the State under its complementary power to abate nuisances that affect the public generally, or otherwise. ${ }^{56}$

The rationale is that people should never be allowed to take by majority vote without compensation what they would have to pay for if they acted cooperatively in their private capacities. To allow otherwise would cause a mass migration from the market and to the political process. But what Justice Scalia does not, or cannot, explain is why this concern with using political power to bypass the market arises only with total takings. The net effect of his position is to invite the endless machinations of the special permit system that South Carolina put in place. Under such a system, delay becomes the norm, and construction that is too expensive or too inconveniently located can be required. The distinction between the total and the partial taking

55. See Robert C. Ellickson, Alternatives to Zoning: Covenants, Nuisance Rules, and Fines as Land Use Controls, 40 U. CHI. L. REv. 681 (1973); Richard A. Epstein, Notice and Freedom of Contract in the Law of Servitudes, 55 S. CAL. L. REv. 1353 (1982).

56. Lucas, 112 S. Ct. at 2900. 
does not exist in the private law of restrictive covenants. Why then should the understanding or reasonable expectations shift so dramatically when we move into the public sphere?

Justice Scalia clearly thought that the distinction made sense, although he did not say so. It seems evident that he resorted to this wholly artificial distinction to avoid having to attack zoning (not to mention rent control) ${ }^{57}$ head on-including the zoning that existed on the Isle of Palms when Lucas purchased his land. After all, zoning is, quite simply, a system of partial restrictions on land use, which would be routinely subject to intense constitutional scrutiny if the total/partial distinction in Lucas is abandoned. But there is no hint as to why a fuller examination of zoning is so far beyond the pale, given the massive abuse of the system that is commonly observed. In the private area, the price for each covenant (whether in cash or kind) increases as the scope of the covenant expands. Why should the government be subject to any different rule? It is, in general, highly unwise to give a single person the power to initiate a transaction by brute force and then to ignore its harmful consequences on other individuals. Yet, that vast power is vindicated when all partial restrictions (and we will never see another total one) are allowable after Lucas. The first of Justice Scalia's claims cannot be sustained by a sound appeal to reasonable expectations.

There still remains a second side to the story, that of state justification of taking without compensation under the police power. Here the initial question should be evident from the above discussion. Restrictive covenants are available to correct any misallocation arising from a landowner's unfettered use of his property. Why then worry about the law of nuisance at all? If one does not like pollution, then one could purchase a restrictive covenant forbidding it. The distinction between ordinary uses, forbidden only by restrictive covenants, and nuisances, restrictive as of right, is foreign to the analysis. Instead of a situation allowing a state to forbid all uses of land without compensation, we could easily veer to a system in which it could forbid none without payment to the affected landowner-Lucas' own indefensible position with respect to total (but not partial) takings.

There is, I think, only one escape from this conclusion. It relies on the same transaction costs theory outlined above. The difference between the ordinary use of land and the nuisance rests on the generalized perception of the relative shift in costs and benefits. ${ }^{58}$ With pollution, the net gain from its practice is normally lower than the costs it inflicts, such that a sole owner of two adjacent properties would take steps to reduce its incidence. The purpose of nuisance law is to replicate the same pattern of behavior when separate ownership (desirable for other efficiency reasons, including the maintenance of competition in residential markets, etc.) shifts either the costs or the benefits to a second landowner.

57. See Pennell v. City of San Jose, 485 U.S. 1, 15 (1988) (Scalia, J., concurring in part and dissenting in part).

58. For more discussion of this topic, see Richard A. Epstein, Regulation-and Contract-in Environmental Law, 93 W. VA. L. REV. 859 (1991). 
With nuisances, an initial allocation that affords the polluter the right to pollute will require many more corrective transactions than the alternative assignment of right in order to achieve the optimal level of pollution. It is preferable for 5 percent of the cases to involve the purchase of an easement to create a nuisance than for 95 percent to involve the purchase of a restrictive covenant to prevent one. Such an allocation properly reflects a world with positive transaction costs, rather than the zero-transaction-cost world of Ronald Coase. ${ }^{59}$ Pick the path which reduces the transaction costs necessary to reach the optimal allocation of resources.

The entire story is, of course, more complicated than this, and further accommodations must be considered. In some instances, low level reciprocal nuisances would typically be the subject of reciprocal covenants, so the "live and let live" rule will allow them to continue as a matter of course. ${ }^{60}$ Conversely, in other situations, as with lateral support easements, where there would likely be restrictive covenants, the law should supply restrictions as a matter of course. Finding the path with the fewest transactional costs en route to the optimal social solution is therefore crucial to understanding the seemingly irreconcilable doctrines of nuisance law. ${ }^{61}$

But can the connection to takings law be forged? Here the Supreme Court generally accepts only a one-way connection: Whatever land uses may be forbidden by neighbors under nuisance law without compensation may similarly be forbidden by the state without compensation. But the converse proposition, though ignored by Justice Scalia, is critical. Whatever uses the neighbors could not prohibit without compensation, the state cannot prohibit without compensation either. In his concurring opinion, Justice Kennedy challenges that proposition:

I agree with the Court that nuisance prevention accords with the most common expectations of property owners who face regulation, but I do not believe this can be the sole source of state authority to impose severe restrictions. Coastal property may present such unique concerns for a fragile land system that the state can go further in regulating its development and use than the common law of nuisance might otherwise permit. ${ }^{62}$

But his prudence, like Justice Scalia's, carries with it some risk. First, the statement misses the close connection between tort and takings law. The function of tort law is to determine when one person owes compensation to another. How could that inquiry not be relevant when the state regulates the conduct of a private party? And if it is not relevant, then we surely need some other test to decide whether compensation is appropriate. Justice Kennedy refers to some "objective rules and customs that can be understood as reasonable by all parties involved." $63 \mathrm{He}$ obviously uses the term "objec-

59. R.H. Coase, The Problem of Social Cost, 3 J.L. \& Econ. 1 (1960).

60. See Bamford v. Turnley, 122 Eng. Rep. 27, 32-33 (Ex. 1862).

61. For a longer account of these points, see Richard A. Epstein, Nuisance Law: Corrective Justice and its Utilitarian Constraints, 8 J. LEGAL STUD. 49 (1979).

62. Lucas, 112 S. Ct. at 2903 (Kennedy, J., concurring).

63. Id. (Kennedy, J., concurring). 
tive" to forestall the mischievous results that follow from allowing the state to regulate without compensation so long as a weary citizenry is well aware of its prior abuses. But more than this negative account is needed to flesh out his objective method. While Justice Kennedy (or for that matter Justice Scalia) is no friend of transaction costs economics, he offers no prescription of his own. Nor does he explain why his own preferred procedure does not yield the undesirable outcomes outlined above. The objective expectations are those that are most likely to maximize total value where neighbors have inconsistent desires. ${ }^{64}$ The common law of nuisance, which he rejects as the limit of state power, is the outgrowth of that process.

Second, Justice Kennedy's statement clearly underestimates the level of sophistication underlying the common law analysis. If the problems of reciprocal risk are of the magnitude that he supposes, then the restrictions he speaks of could be analyzed within the common law framework. For example, the common law negative easement of lateral support is analogous to South Carolina's claims about the relationship between private construction and public lands. If the state could show that a public beach received any lateral support from private lands, then some restrictions might be justified without compensation. But it is one thing to show that beaches are fragile, and quite another to show that construction of an ordinary home (i.e., a home that could never be regarded as a nuisance off the coastline) becomes a nuisance simply by virtue of its location. Any small alteration made in the beachfront will be dwarfed by the far greater damage wrought by natural forces. The risk that a house will be wiped out by a storm is far greater than the risk that its construction will cause any damage-a risk that many landowners would be willing to take, given the market value of the property.

Third, Justice Kennedy's statement provides no insight into the relative magnitude of the values at stake on both sides of the conflict. Independent of the regulation (and subject to the zoning restrictions) the land in Lucas is worth over one million dollars to its private owner. From that fact we can infer two points. First, the subjective value of that land to its owner is at least as high, and, with respect to plots that are held for use, probably higher. Second, we know that comparable plots along the beach will have comparable values, assuming the market remains in equilibrium. It should therefore be simple to calculate the total loss in market value if the regulation is given its more general effect. As the total coastline subject to the regulation spans approximately several hundred miles, a conservative estimate suggests that billions of dollars in private use are lost, with comparable losses in the tax base as well. These private losses are, moreover, social

64. For further illustration of the same attitude toward reasonable expectations in the private law, see Katz v. United States, 389 U.S. 347 (1967), a case that caused Justice Kennedy great angst in his concurring opinion. See supra note 10. The parallels between the constitutional principles and the private law extensions of the law of trespass are developed in Richard A. Epstein, A Common Lawyer Looks at Constitutional Interpretation, 72 B.U. L. REv. 699, 713-17 (1992). In essence the law of privacy against snooping is an exact parallel to the noninvasive nuisances actionable at common law. 
losses in any calculation that seeks to determine social welfare by aggregating private welfare.

Given the staggering private costs, a salient question is how much does the public gain from this enterprise? The public benefit is surely greater than zero, and one possible implication of Justice Kennedy's position (albeit one that he would prefer to resist, if he could find a middle ground) is that so long as the public benefits to nonlandowners are positive, then it is inappropriate for courts to second-guess the legislature by ordering compensation. That test for social benefit will certainly pose no obstacle to any needed form of social regulation. But by the same token, vast amounts of overambitious, costly, and even silly legislation will slide through. In this case, for example, the South Carolina legislature had to think long and hard before appropriating ten million dollars for the renourishment of the beach. ${ }^{65}$ The empirical question imposed by my approach to the nuisance question is whether there are any public benefits comparable to the billions in private losses caused by placing a total, or even partial, moratorium on the construction of ordinary single-family homes. I suspect that the social gains derived from protecting the beachfront against erosion, or from reducing the potential damage from hurricanes, could amount to thousands or millions of dollars, but not the billions of dollars of lost use value.

Setting the rights in favor of the landowner makes eminently good sense. In the few cases where public intervention is necessary, the purchase can be easily arranged. But in the many cases where the regulation is driven by the worst-case scenarios so common in environmental matters, the Takings Clause (now the Just Compensation Clause) will serve as a welcome restraint on the appetite of government. If, in a particular case, the net social benefits exceed the private losses, there might be a case for regulation without compensation. Such a case would suggest that the intended use of the landowners was never included in the initial bundle of private property rights. But given the system of empirical evaluations implicit in any assignment of property rights, it becomes permissible, if not necessary, to ask: Where are the billions in social benefits from legislation that inflicts billions in private and social losses?

There is then ample reason to reject Justice Kennedy's approach. Under Justice Scalia's opinion, which will apply at trial, the outcome should be clear. The connection between nuisance prevention (or lateral support) and the building restriction is tenuous at best. ${ }^{66}$ The other objectives of the legislation-the developmental retreat along the beach, the promotion of tourism and leisure time for citizens-are by no stretch of the imagination related to

65. Amicus Curiae Brief, supra note 5, at 1240 (citing Trial Transcript at 69).

66. The same is true for the prevention of hurricane damage. See Brief of Nueces County, Texas as Amici Curiae in Support of Respondent, Lucas v. South Carolina Coastal Council, 112 S. Ct. 2886 (1992), available in LEXIS, Genfed Library, BRIEFS File, at *9-*12. For a critique of that position, arguing that any prohibition on construction is wildly excessive under the circumstances, see Epstein, Ruminations, supra note 5, at 1229-31. The point was not addressed in Justice Scalia's opinion. 
the state's police power. The selective imposition of these restrictions on the breaker islands, while allowing new construction in major urban centers, is analogous to creating a state park without paying for the change. The trial on these issues might be complicated by a set of needless political barriers, but on these facts at least, Lucas is entitled to an easy victory.

The more difficult questions regarding the overall state of takings law, however, remain unresolved. The present law is in chaos because of its muddled conceptual foundations. Too often the justices rely on a conception of reasonable expectations that is drained of all its explanatory power. Too often conceptual coherence is sacrificed because the Justices are afraid to face the broad implications of the Takings Clause. The fear arises because the clause is broad, not because its implications are mischievous. Lucas is a case of disappointed expectations because Justice Scalia embraced the private law analogies on the police power question when it was too late to do any good. What he should have done was make clear that the categorical distinction between partial and total takings has no parallel in private law and no place in public law. The Fourth Amendment jurisprudence that refuses to limit "searches and seizures" to physical invasions and criminal trespasses is a model for takings jurisprudence that should have been stressed instead of ignored. In order for Justice Scalia's reasoning to work, it would have to bring many more forms of land use regulation within the Takings Clause, where they could receive the close scrutiny and swift dispatch that most of them so richly deserve. 